\title{
Journal of Brachial Plexus and Peripheral Nerve Injury
}

\section{Bilateral superficial peroneal nerve entrapment secondary to anorexia nervosa: a case report Teoman Toni Sevinç, Aydıner Kalacı*, Yunus Doğramacı and Ahmet Nedim Yanat}

Address: Dept. of Orthopaedics and Traumatology, Mustafa Kemal University, Faculty of Medicine, Antakya, Hatay, Turkey

Email: Teoman Toni Sevinç - sevinctt@mynet.com; Aydıner Kalacı* - orthopedi@gmail.com; Yunus Doğramacı - yunus_latif@yahoo.com; Ahmet Nedim Yanat - an_yanat@yahoo.com

* Corresponding author

\section{Published: 27 April 2008}

Journal of Brachial Plexus and Peripheral Nerve Injury 2008, 3:12 doi:I0.1186/1749-722I-312

This article is available from: http://www.jbppni.com/content/3/I/I2

(C) 2008 Sevinç et al; licensee BioMed Central Ltd.

This is an Open Access article distributed under the terms of the Creative Commons Attribution License (http://creativecommons.org/licenses/by/2.0), which permits unrestricted use, distribution, and reproduction in any medium, provided the original work is properly cited.
Received: 14 January 2008

Accepted: 27 April 2008

\begin{abstract}
We report a case of severe weight loss secondary to anorexia nervosa causing bilateral superficial peroneal nerve entrapment in a young female patient who was treated successfully by bilateral surgical decompression.
\end{abstract}

\section{Background}

Among entrapment neuropathies, superficial peroneal nerve (SPN) entrapment is relatively rare [1-8] and only a few bilateral cases have been reported in the literature $[9,10]$.

Severe weight loss, as a result of anorexia nervosa, associated with common peroneal nerve entrapment is very rare [11-17] and SPN involvement alone has not been described in the literature published in English. Bilateral presentation is always related to systemic cause rather than local mechanical compression.

Herein we report a case of severe weight loss secondary to anorexia nervosa causing bilateral SPN entrapment in a young female patient who was treated successfully by bilateral surgical decompression.

\section{Case presentation}

A 20-year-old, female university student presented to our outpatient orthopaedic clinic with a two month history of vague pain on the outer border of both legs, and numb- ness over the dorsum of the feet and big toes. Her symptoms were exacerbated by walking and running and partially relieved by elevation. She had to stop to rest after 30 minutes of walking because of intolerable pain.

There was neither history of trauma or surgery to the lower limb nor history of lower back problems. There was, however, a history of severe weight loss of ( $30 \mathrm{~kg}$ ) during the previous six months and the patient was diagnosed with anorexia nervosa using criteria from the American Psychiatric Association's Diagnostic and Statistical Manual of Mental Disorders (DSM-IV-TR) and the World Health Organization's International Statistical Classification of Diseases and Related Health Problems (ICD).

Physical examination revealed bilateral tender points approximately $11 \mathrm{~cm}$ proximal to the ankle joint on the outer surface of the leg, Tinel sign was also positive bilaterally. There were sensory deficits on the dorsum of both big toes but no muscle weakness or abnormal reflexes. 
Examination of the lumbar spine and lower limbs revealed no clinical abnormalities in the joints and there was neither suspicion of nerve root compression at the level of the lumbar spine nor nerve entrapment at the neck of the fibula.

Radiographic examination of the lumbar spine, legs and feet were normal and EMG studies were positive for bilateral entrapment neuropathy of the SPN proximal to the ankle joint with no abnormality of the common peroneal nerves or of the proximal nerve roots.

After preoperative assessment, the patient was admitted for surgical treatment with the diagnosis of SPN entrapment. The operation was done under general anaesthesia, using pneumatic tourniquet. Bilateral explorations of the site of tenderness revealed adhesions of both SPNs to the fascia with perineural fibrosis. Careful dissections were done to free the nerves and neurolysis was successfully performed (Figure 1). The nerves were freed distally and proximally by splitting the overlying fascia for a few centimetres above and below the site of entrapment.

Symptoms of bilateral peroneal nerve entrapment were relieved immediately and completely in the postoperative period. Physiotherapy was started immediately to prevent postoperative adhesions. No recurrence was observed in the first year following the operation.

\section{Discussion}

Superficial peroneal nerve syndrome is an entrapment neuropathy that usually results from mechanical compression of the nerve at or near the point where the nerve pierces the fascia to travel within the subcutaneous tissue.

A thorough and accurate knowledge of the course of the SPN and its relationships is essential to understand the pathophysiology, and a thorough and careful physical examination is important for diagnosing this condition. Stephens et al. described a physical sign to identify the distal subcutaneous course of the SPN below the skin, primarily by means of plantar flexion and inversion of the ankle and foot and, secondarily by a passive flexion of the fourth toe [1].

In his study Styf, described 3 provocative tests for nerve compression at rest at rest following exercise [2]. In the first test, pressure is applied over the anterior intermuscular septum while the patient actively dorsiflexes the ankle. In the second test, the foot is passively plantar flexed and inverted at the ankle. In the third test, while the patient maintains the passive stretch, gentle percussion is applied over the course of the nerve. These tests are useful in competitive athletes who have symptoms suggestive of exercise-induced compartment syndrome.

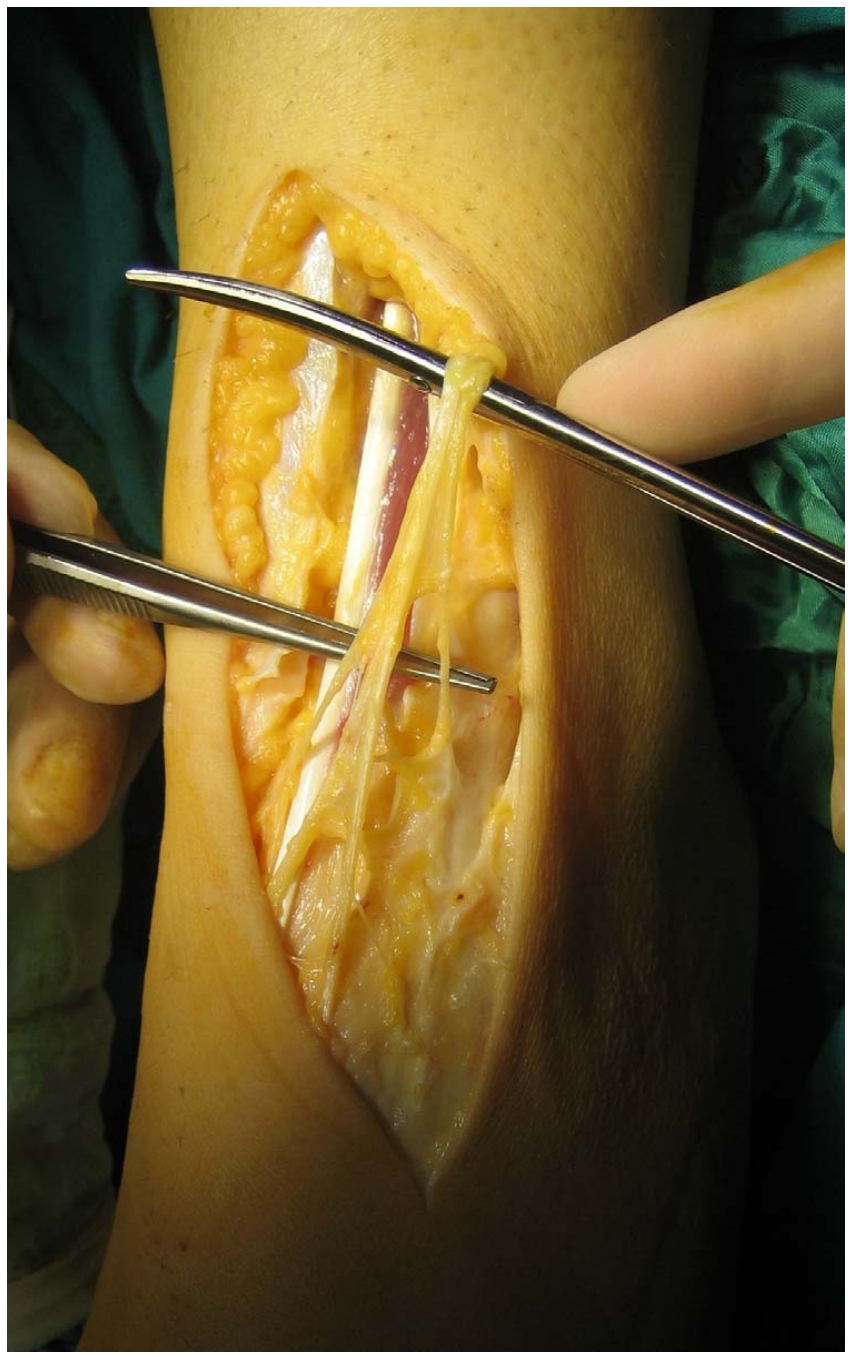

Figure I

Photograph at operation showing the superficial peroneal nerve.

Electrophysiological studies are helpful for the diagnosis, however, normal conduction velocity may be found especially at rest which does not exclude compression of the superficial peroneal nerve [2].

Injection of the nerve with lidocaine or Marcaine just above the site of involvement may be the most valuable diagnostic tool. The patient can define the extent of relief obtained from such an injection, which can be helpful in defining the zone of injury and expected relief from surgical release or excision.

Entrapment of the superficial peroneal nerve has traumatic and non traumatic causes. Local trauma and compression are the most common causes of nerve entrapment. This may be due to recurrent stretch injuries 
or certain positions like prolonged kneeling and squatting, which cause perineural fibrosis $[17,18]$. Oedema after trauma may result in a mini compartment syndrome which may occur when the tunnel was fibrotic, of low compliance and longer than $3 \mathrm{~cm} \mathrm{[2].} \mathrm{Chronic} \mathrm{or} \mathrm{exer-}$ tional lateral compartment syndrome can also cause compression of the superficial peroneal nerve, particularly in athletes $[19,20]$. Fasciotomy of the anterior compartment for chronic anterior compartment syndrome may also cause compression of the SPN nerve [19].

Nontraumatic causes of SPN entrapment are commonly due to anatomical variations such as fascial defects, with or without muscle herniation about the lateral lower leg, where the nerve is entrapped as it emerges into the subcutaneous tissue or a short peroneal tunnel proximally. Nerve compression in patients with fascial defects is explained by the normal increase in muscle relaxation pressure and intramuscular pressure at rest during and after exercise. This increase is sufficient to cause herniated muscle tissue and this can impinge upon or compresses the nerve [20].

Lowdon reported a case of an abnormally long course of the SPN nerve through the deep fascia which was thought to have caused compression. Exercise may have exacerbated the symptoms by producing mechanical irritation or by raising the pressure in the peroneal compartment and thus increasing compression of the nerve [3].

\section{Conclusion}

In our case, the bilateral involvement forced us to think about a systemic cause of SPN entrapment. The patient had severe loss of weight in a period of few months due to previously undiagnosed anorexia nervosa which may have caused changes in the subcutaneous tissues that led to adhesions and perineural fibrosis. Although the exact cause is unknown; SPN entrapment should be kept in mind especially in patients with severe weight loss and changes in body habits.

\section{Competing interests}

The authors declare that they have no competing interests.

\section{Acknowledgements}

Written informed consent was obtained from the patient for publication of this case report and accompanying images. A copy of the written consent is available for review by the Editor-in-Chief of this journal.

\section{References}

I. Stephens MM, Kelly PM: Fourth toe flexion sign: a new clinical sign for identification of the superficial peroneal nerve. Foot Ankle Int 2000, $21: 860-863$.

2. Styf J: Entrapment of the superficial peroneal nerve. Diagnosis and results of decompression. J Bone Joint Surg $\mathrm{Br}$ 1989, 7I:13I-135.

3. Lowdon IM: Superficial peroneal nerve entrapment. A case report. J Bone Joint Surg Br 1985, 67:58-59.
4. Yang LJ, Gala VC, McGillicuddy JE: Superficial peroneal nerve syndrome: an unusual nerve entrapment. Case report. J Neurosurg 2006, 104:820-823.

5. Styf J, Morberg P: The superficial peroneal tunnel syndrome. Results of treatment by decompression. J Bone Joint Surg $\mathrm{Br}$ 1997, 79:80I-803.

6. Daghino W, Pasquali M, Faletti C: Superficial peroneal nerve entrapment in a young athlete: the diagnostic contribution of magnetic resonance imaging. J Foot Ankle Surg 1997, 36:170-172.

7. Kernohan J, Levack B, Wilson JN: Entrapment of the superficial peroneal nerve. Three case reports. J Bone Joint Surg $\mathrm{Br} 1985$, 67:60-61.

8. Banerjee T, Koons DD: Superficial peroneal nerve entrapment. Report of two cases. J Neurosurg 1981, 55:991-992.

9. Saragaglia D, Farizon F, Drevet JG, Butel J: Peroneal nerve entrapment syndrome of the front of the foot. Treatment by neurolysis. Apropos of a bilateral case. Rev Chir Orthop Reparatrice Appar Mot 1986, 72:579-58I.

10. McAuliffe TB, Fiddian NJ, Browett JP: Entrapment neuropathy of the superficial peroneal nerve. A bilateral case. J Bone Joint Surg $\mathrm{Br}$ 1985, 67:62-63.

II. Constanty A, Vodoff MV, Gilbert B, Dantoine F, Roche JF, Piguet C, Tabaraud $F$, de Lumley $L$ : Peroneal nerve palsy in anorexia nervosa: three cases. Arch Pediatr 2000, 7:316-317.

12. Lutte I, Rhys C, Hubert C, Brion F, Boland B, Peeters A, Van Den Bergh $P$, Lambert M: Peroneal nerve palsy in anorexia nervosa. Acta Neurol Belg 1997, 97:25I-254.

13. Kershenbaum A, Jaffa T, Zeman A, Boniface S: Bilateral foot-drop in a patient with anorexia nervosa. Int J Eat Disord 1997, 22:335-337.

14. MacKenzie JR, LaBan MM, Sackeyfio AH: The prevalence of peripheral neuropathy in patients with anorexia nervosa. Arch Phys Med Rehabil 1989, 70:827-830.

15. Schott GD: Anorexia nervosa presenting as foot drop. Postgrad Med J 1979, 55:58-60.

16. Kopell HP, Thompson WAL: Peripheral entrapment. neuropathies of the lower extremity. N Engl J Med 1960, 262:56-60.

17. Stack RE, Bianco AJ Jr, Maccarty CS: Compression of the common peroneal nerve by ganglion cysts: report of nine cases. J Bone Joint Surg Am 1965, 47:773-778.

18. Styf J: Diagnosis of exercise-induced pain in the anterior aspect of the lower leg. Am J Sports Med 1988, 16:165-169.

19. Styf JR, Körner LM: Diagnosis of chronic anterior compartment syndrome in the lower leg. Acta Orthop Scand 1987, 58: I39-I 44.

20. Styf JR, Körner LM: Microcapillary infusion technique for measurement of intramuscular pressure during exercise. Clin Orthop Relat Res 1986, 207:253-262.

\begin{tabular}{|l|}
\hline Publish with Biomed Central and every \\
scientist can read your work free of charge \\
"BioMed Central will be the most significant development for \\
disseminating the results of biomedical research in our lifetime. " \\
Sir Paul Nurse, Cancer Research UK \\
Your research papers will be: \\
• available free of charge to the entire biomedical community \\
• peer reviewed and published immediately upon acceptance \\
• cited in PubMed and archived on PubMed Central \\
• yours - you keep the copyright \\
Submit your manuscript here: \\
http://www.biomedcentral.com/info/publishing_adv.asp
\end{tabular}

